\title{
Environmental Innovation Model with Product and Outcomes Dimension of Green Kampung in Surabaya City
}

\author{
Filipus Priyo Suprobo, Ririn Dina Mutfianti* \\ Department of Architecture, Faculty of Engineering, Widya Kartika University, Surabaya, 60113, Jawa Timur, Indonesia
}

Received October 5, 2020; Revised December 15, 2020; Accepted January 20, 2021

\section{Cite This Paper in the following Citation Styles}

(a): [1] Filipus Priyo Suprobo, Ririn Dina Mutfianti , "Environmental Innovation Model with Product and Outcomes Dimension of Green Kampung in Surabaya City," Civil Engineering and Architecture, Vol. 9, No. 1, pp. 1 - 8, 2021. DOI: 10.13189/cea.2021.090101.

(b): Filipus Priyo Suprobo, Ririn Dina Mutfianti (2021). Environmental Innovation Model with Product and Outcomes Dimension of Green Kampung in Surabaya City. Civil Engineering and Architecture, 9(1), 1 - 8. DOI: 10.13189/cea.2021.090101.

Copyright $\odot 2021$ by authors, all rights reserved. Authors agree that this article remains permanently open access under the terms of the Creative Commons Attribution License 4.0 International License

\begin{abstract}
The background of this research is the phenomenon of Surabaya as one of the Global Green Cities, besides Maanheim from Germany and Zhejiang Province from China, in the "Sustainable City and Human Settlements Award" by the United Nations 2017. This investigation is presented as a continuation of previous research on sustainable green cities through measuring the success rate of environmental innovation. Therefore, the aim of this study is to examine the extent to which environmental in-novation is explained by the dimensions of outcomes and green kampung products. The research method used is an explanative quantitative approach. Furthermore, data collection was carried out using a non-probability sampling with snowball techniques, obtaining 71 respondents. It was more than the planned minimum of 52 samples. Statistical analysis consisted of second-order confirmatory factors which were recorded as sub-structural equation modeling. The results showed that the model developed had a fairly good fit. Meanwhile, the green kampung product dimension with three indicators was declared valid to contribute $93.01 \%$, while the outcomes dimension gave $92.89 \%$. These two dimensions together in the overall complex model were able to measure the green kampung environmental innovation construction by $65.1 \%$. The novelty in this research is the dimensions of the outcomes of the green kampung in the form of appreciation, the values of creativity and innovation of the residents as well as mutual awareness to
\end{abstract}

care for the environment. This is a new determinant of environmental innovation performance, besides products for urban kampung.

Keywords Environmental Innovation, Green Kampung, Green Products, Green Outcomes

\section{Introduction}

Environmental problems cannot be separated from the many interests in an area. A landscape certainly changes dynamically, as many important environmental changes are made over a certain period of time [1]. The Ecological development of an area is commonly known as environmental innovations, motivated by several aspects, in terms of: 1) the concern about lack of natural resources due to industrial behavior [2], 2) economic encouragement demanding high competitiveness in green practice [3-5], and 3) social aspects in form of public awareness levels for a changed lifestyle, to reduce environmental degradation and global warming [6]. These three factors are known to underly the emergence of environmental innovation influenced by progress level of an entity's economic interests, either government or industry. Meanwhile, provided government policies in Asia, including Indonesia, are formulated to invest more in economic infrastructure 
rather than social and environmental sectors, the industry's capacity will however tend to follow the administrative policies [7]. Furthermore, reports from Asian Development Bank showed the existence of inequality of income obtained by a map of investment expenditure prioritizing economic infrastructure [8].

This research was embarked on due to the choosing of Surabaya city, Indonesia as a Global Green City alongside Maanheim in Germany and Zhejiang Province from China all nominated in United Nations (UN) "Sustainable City and Human Settlements Award" (SCAHSA) on October 31, 2017 [9-10]. The Surabaya region is internationally recognized because it was able to realize 1) arrangement of slum settlement; 2) greening the city through adequate green open space, and 3) economic empowerment of the city community by prioritizing environmentally friendly issues. In addition, kampungs in Surabaya utilize the available resources in an environmentally friendly way to achieve social and economic independence. Previous research by Suprobo and Mutfianti on sustainable green city model [11], provided a result showing the dynamic capacity of this urban areas continues to move and grow through utilization of ecological resources to turn the wheels of environmental innovation sustainability, categorized as product outcomes felt by green kampungs. This phenomenon proves environmental innovation is actually generated from the high motivation of social aspects by using the atmosphere to create an economic feature for sustainability of community entity, both government and industry.

The civil society of this urban kampung function to complete and balance Surabaya city's government [12]. This urban community grows as an entity of environmentally-based self-subsistent economical aspect with a hybrid organizational function, specifically profit and social-oriented, because it subsidized commercial organization transacting with a group of beneficiaries [13-15].

The research conducted by Chang and Chen [16], outlined green innovation as hardware or software development related to green products or processes, including technologies involved in energy saving, pollution prevention, waste recycling, friendly product design and environmental or ecological management of entities. Furthermore, further studies by Albort Morant et al. [17-19] shared a similar statement and illustrated environmental innovation as the main purpose to reduce or prevent damaged ecology by enabling entities meet new consumer demands, create value and increase revenue. According to Nanath and Pillai [20], environmental innovation is divided into two performances, specifically the green product and process innovation performance. In addition, green product innovation basically deals with performance of a brand development in relation to the environment, energy saving, pollution prevention, waste recycling and reduced toxicity, while green process innovation is defined as performance in activities related to ecological practice. Meanwhile, these products when examined more deeply are discovered not to contain only the final result, but processes as well, for example 1) apart from Waste Bank savings, it is better to find the management 2) apart from processed water products, sewage treatment equally needs to be found; 3 ) besides compost, better fertilizer processing technology are to be found, and lastly, apart from urban kampung tourism activities, the management is also found.

Meanwhile, outcome or benefits for green kampungs as an environmental innovation performance refers to the research of Pereira et al [21] and Wilts et al [22] emphasizing on increase in social welfare. The tendency of contextual adjustments between social changes and environment of this community was carried out as an effort to survive at first. This ultimately made the kampung more empowered and increased bargaining positions in economic aspect, admidst life's competition. According to Wilts et al. [22] apart from new goods, processes, organizational changes, or marketing methods within an entity, environmental innovation also come in the form of a broader change with systemic implications for the environment, economy and social. Moreover, green kampung community with cadres and caring members choose to determine the destiny and exercise rights as collaborators together with Surabaya government to make a sustainable city.

Furthermore, based on previous research and theories, problems of this study were formulated more on whether the product dimensions in addition to outcomes are environmental innovation construct manifestations in Surabaya. This study therefore, aims to test the empirical relationship between green kampung environmental innovation with dimensions of products and outcomes expected to bring benefits, especially in driving continuous ecological development of community's socio-economic non-governmental organization entity. However, if the result of this test is positive, then the phenomenon of hybrid organizations function [13-15] prioritizing empowerment of social and economic missions with environmental issues, especially in Surabaya urban kampungs, will oppose many of Martinez's arguments [7].

The context of green kampung entities in functions of environmentally-based hybrid organizations is a new finding when compared to profit organizations using the environment. Meanwhile, even though this empirical test puts environmental innovation model in product and outcomes dimensions as in previous studies, however novelty lies on the use in context of green kampung entities.

\section{Materials and Methods}

This research comprised of an explanative quantitative 
research approach to testing hypotheses or relationship between latent and indicator. The procedures in this explanative research stage are analysis of second order factor confirmation including: (1) developing a hypothetical model or conceptual framework, (2) determining the variables, (3) developing instruments based on previous studies, (4) determining respondents, (5) data collection through electronic media, (6) data analysis using Generalized Structural Component Analysis (GeSCA).

However, in order to provide an overview and direct assumptions about the variables to be studied, a conceptual framework is compiled based on results of the main development study by Suprobo and Mutfianti [11]. Furthermore, for related product outcomes departing from sources of Chang and Chen [16], Albort Morant et al. [17-19], Huang and Li [23] in addition to Nanath and Pillai [20], is simplified into: 1) products with ecological materials, 2) product packaging capable of reducing the use of plastic materials, 3) products using expired return. Meanwhile, for the outcomes on green kampungs, the research of Pereira et al [21] and Wilts et al [22], were developed into: 1) the welfare of kampung residents, 2) respect for the kampung, 3) creativity and innovation from citizens, and 4) awareness of the ecological practices. The outcomes felt by this green kampung is the first order factor or dimension used to determine the existence of environmental innovation variable as a second order factor (as shown in Figure 1).

Based on the conceptual model above, two hypotheses were proposed to be tested: 1) The creation of green kampung product known as a dimension of environmental innovation construct; and 2) Production of various outcomes.

The unit used for analysis was the community socio-economic self-subsistent in kampung located at Surabaya city with a social mission and economic benefit alongside values to prioritize environmentally friendly activities. This establishment is described to have a dynamic and innovative business pattern, together with an ecological strategy in a sustainable manner [24]. In addition, four organizational models, including non-profit entrepreneurship, cooperatives, MSME, and public sector [13] possibly perform activities in terms of waste minimization, recycling, resource efficiency, environmental management and audits, as well as pollution control during production process [3]. The study employed non-probability sampling with snowball techniques. This approach was chosen on the basis of consideration because of the limited existence of the organization population that has not been officially measured by the city government and the severe conditions of the Covid-19 pandemic in Surabaya. Furthermore, the number of samples collected was 71 respondents consisting of owners, managers, or cadres as representatives of the kampung non-governmental organizations. Meanwhile, the total figure obtained exceeded the minimum requirement of 52 samples when associated with the highest number of coefficient paths leading to latent variables [25]. Table 1 shows data collected.

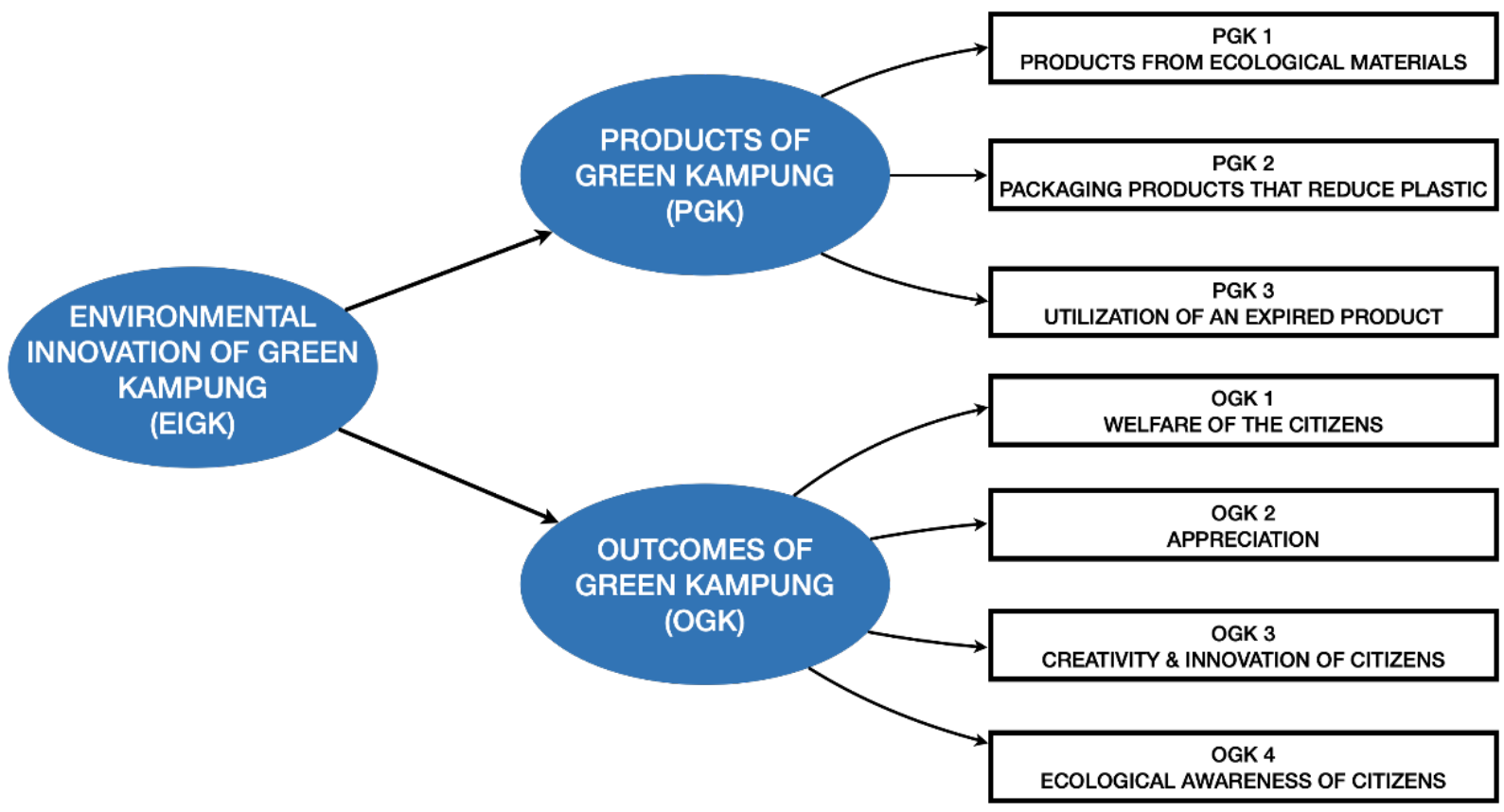

Figure 1. Conceptual Model of Green Kampung Environmental Innovation 
Table 1. Respondent data

\begin{tabular}{|c|c|c|}
\hline Sample Indicators & $\mathrm{n}$ & $(\%)$ \\
\hline $\begin{array}{l}\text { a) Gender } \\
\text { Male } \\
\text { Female } \\
\text { Total }\end{array}$ & $\begin{array}{l}34 \\
37 \\
71\end{array}$ & $\begin{array}{c}47.9 \\
52.1 \\
100.0\end{array}$ \\
\hline $\begin{array}{l}\text { b) Age } \\
18-<24 \\
24-<30 \\
30-<40 \\
>40 \\
\text { Total }\end{array}$ & $\begin{array}{c}4 \\
9 \\
18 \\
40 \\
71\end{array}$ & $\begin{array}{c}5.6 \\
12.7 \\
25.4 \\
56.3 \\
100.0\end{array}$ \\
\hline $\begin{array}{l}\text { c) Education } \\
\text { Junior High School } \\
\text { Senior High School } \\
\text { Diploma } \\
\text { Bachelor } \\
\text { Master } \\
\text { Total }\end{array}$ & $\begin{array}{c}1 \\
12 \\
7 \\
40 \\
11 \\
71\end{array}$ & $\begin{array}{c}1.4 \\
16.9 \\
9.9 \\
56.3 \\
15.5 \\
100.0\end{array}$ \\
\hline $\begin{array}{l}\text { d) Status in Organization } \\
\text { Owners } \\
\text { Managers } \\
\text { Owners as well as Managers } \\
\text { Total }\end{array}$ & $\begin{array}{c}4 \\
29 \\
38 \\
71\end{array}$ & $\begin{array}{c}5.6 \\
40.8 \\
53.6 \\
100.0\end{array}$ \\
\hline $\begin{array}{l}\text { e) Business Groups / Organizations in Hybrid Functions } \\
\text { Social / non-profit entrepreneurship } \\
\text { Cooperative } \\
\text { Small and medium scale social business (MSE) } \\
\text { Public sector service ventures } \\
\text { Total }\end{array}$ & $\begin{array}{c}9 \\
7 \\
41 \\
14 \\
71\end{array}$ & $\begin{array}{c}12.7 \\
9.9 \\
57.7 \\
19.7 \\
100.0\end{array}$ \\
\hline $\begin{array}{l}\text { f) Ecological Practice Activities developed } \\
\text { Unique crafts from waste } \\
\text { Plastic waste cooperatives / banks } \\
\text { Herbal Food and Beverages } \\
\text { Business with minimizing plastic waste } \\
\text { Preservation of the environment and surrounding areas } \\
\text { Reuse products } \\
\text { Environmental tourism } \\
\text { Total }\end{array}$ & $\begin{array}{c}7 \\
5 \\
10 \\
3 \\
29 \\
14 \\
3 \\
71\end{array}$ & $\begin{array}{c}9.9 \\
7.1 \\
14.1 \\
4.2 \\
40.8 \\
19.7 \\
4.2 \\
100.0\end{array}$ \\
\hline $\begin{array}{l}\text { g) Organization location } \\
\text { Central Surabaya } \\
\text { West Surabaya } \\
\text { East Surabaya } \\
\text { North Surabaya } \\
\text { South Surabaya } \\
\text { Total }\end{array}$ & $\begin{array}{c}11 \\
14 \\
13 \\
5 \\
28 \\
71\end{array}$ & $\begin{array}{c}15.5 \\
19.7 \\
18.3 \\
7.1 \\
39.4 \\
100.0\end{array}$ \\
\hline
\end{tabular}

The method used to obtain information was a non-test model with an online questionnaire where question/statement consisted of seven indicator variables. In addition, data was measured using an interval scale with a bipolar adjective technique in the answer options, "strongly disagree to agree had a range of values 1 to $7 "$. The mean, standard deviation, correlation, parameter statistical test and others were computed for the system, excluding absolute measurements. Furthermore, the collection procedure was performed from April to July
2020 by initially requesting the consent of interested individuals, known to fill out an online questionnaire. Also, each respondent was asked for a reference to the researcher as the informant from a similar organizational model.

This study uses a variance basis for the data analysis process, with the following considerations: (1) Component based SEM has high flexibility towards a model built on strong, weak and even explorative theoretical foundations (at the test/predictive level) ; (2) Measurement patterns are accepted from both formative and reflective indicators, 
where markers are possibly used based on theory or from previous research results; (3) The assumption of a multinormal distribution for a model is not required. (4) Variance-based SEM uses 30-100 samples [26].

Furthermore, evaluation of the Outer and inner model is performed to ensure correctness. Table 2 to 4 conveys the requirement for each part of this analysis based on references from Aprilia and Ghozali [27], Chin [28], Fornell and Larcker [29], Hair Jr. et al. [30], Hanseler [31], and Hwang and Takane [32].

Table 2. Outer Model Evaluation (Measurement Model)

\begin{tabular}{|c|c|}
\hline $\begin{array}{l}\text { Loading } \\
\text { Factor }\end{array}$ & $\begin{array}{l}\text { A latent construct is considered to have good } \\
\text { convergent validity on instances where each loading } \\
\text { factor for the forming indicators are significant and } \\
\text { more than 0.6. }\end{array}$ \\
\hline $\begin{array}{l}\text { Discriminant } \\
\text { Validity }\end{array}$ & $\begin{array}{c}\text { AVE square root }>\text { correlation between latent } \\
\text { constructs }\end{array}$ \\
\hline $\begin{array}{l}\text { Composite } \\
\text { Reliability }\end{array}$ & $\begin{array}{l}\text { Composite Reliability measures internal } \\
\text { consistency and possibly measured by possessing an } \\
\text { accurate knowledge of the value }>0.7 \text { for } \\
\text { Confirmatory Research and }>0.6 \text { is acceptable for } \\
\text { Exploratory Research. }\end{array}$ \\
\hline $\begin{array}{l}\text { Average } \\
\text { Variance } \\
\text { Extracted }\end{array}$ & $\begin{array}{l}\text { The Average Variance Extracted (AVE) value is } \\
\text { used to measure the reliability of the latent construct } \\
\text { component scores. The output is recommended to } \\
\text { not exceed } 0.5 \text {. }\end{array}$ \\
\hline
\end{tabular}

Table 3. Inner Model Evaluation (Structural Model)

\begin{tabular}{|c|c|}
\hline $\begin{array}{c}\text { R2 for } \\
\text { endogenous } \\
\text { latent } \\
\text { variables }\end{array}$ & $\begin{array}{c}\text { R2 results of 0.67, 0.33, and 0.19 were obtained for } \\
\text { endogenous latent variables in the structural model, } \\
\text { and therefore indicating the model as "good", } \\
\text { "moderate", and "weak". }\end{array}$ \\
\hline $\begin{array}{c}\text { Estimated } \\
\text { path } \\
\text { coefficients }\end{array}$ & $\begin{array}{c}\text { The estimated values for the path relationships in the } \\
\text { structural model ought to be significant. This output } \\
\text { is possibly obtained through bootstrapping } \\
\text { procedures. }\end{array}$ \\
\hline
\end{tabular}

Table 4. Evaluation of the Goodness Fit Model

\begin{tabular}{|c|c|}
\hline FIT & $\begin{array}{c}\text { FIT describes the differences between the model and the } \\
\text { data. This measure is expected to assess the extent to which } \\
\text { a model fits the data and also to compare alternative } \\
\text { models. The values obtained range from } 0 \text { to } 1 \text {, and higher } \\
\text { outcomes influence greater data variance, as explained by } \\
\text { the model. }\end{array}$ \\
\hline AFIT & $\begin{array}{r}\text { The FIT value is influenced by the model complexity. } \\
\text { Therefore, an unaffected Adjusted FIT (AFIT) is } \\
\text { developed. Hence, the model responsible for the most } \\
\text { significant AFIT is considered the best choice. }\end{array}$ \\
\hline GFI & $\begin{array}{r}\text { The GFI value is close to 1 (>0.9) indicating good fit [33]. } \\
\text { SRMR }\end{array}$ SRMR values close to 0 is an indication of good fit [33]. \\
\hline
\end{tabular}

\section{Results and Discussions}

\subsection{Measurement Model}

The first order construct of green kampung products demonstrated good convergent validity, while the total indicators had a loading factor $>0.60$ and were significant with a statistical $\mathrm{T}$ value above 1.96 . The composite reliability measuring internal consistency of products was adequate, showing a value of $0.878(>0.7)$. This is also supported by the Average Variance Extracted (AVE), estimated to measure the green kampung component reliability, showing a score of $0.706(>0.5)$. Furthermore, the construct also has a good discriminant validity, indicating an AVE square root value (0.840) higher compared to the correlation between kampung product concept and outcomes (0.727). This principle states the existence of a poor correlation between the components forming a different structure and height. Hence, a simple explanation for the manifested construct is derived.

The indicators for community welfare were removed from the model to achieve a good convergent validity value with all indicators having a loading factor $>0.60$ and significant on T statistic above 1.96. However, composite reliability was 0.859 (> 0.7) and considered good, while the AVE for component reliability outcomes was $0.671(>0.5)$. The result discriminant validity construct for green kampungs was fit, considering an AVE square root value of 0.819 , which is higher than the output observed between construct for sample and results (0.727). These values suggest the modeling components outcome for green kampung and further explain the manifested construct. Table 5 shows detailed explanations.

\subsection{Results of Structural Models and Goodness Fit}

The structural model calculation shows a detailed environmental innovation. However, the second order construct of green kampung evaluated the dimensions and fabricated outcomes. Table 6 illustrates the coefficients paths between EIGK $\rightarrow$ PGK and EIGK $\rightarrow$ OGK as significant at $\mathrm{T}$ statistic (above 1.96). The determination coefficient $\left(\mathrm{R}^{2}\right)$ of PGK and OGK was 0.8645 and 0.8631 , respectively, indicating a relationship between the observed variables and estimated sample product, as well as an outcome dimension of $86.45 \%$, and $86.31 \%$ correspondingly. Table 7 justifies the structural model for environmental innovations in green kampung as adequate, considering the high value in coefficient determination (0.67). 
Table 5. Loading Factor, Composite Reliability and AVE of First Order Construct

\begin{tabular}{|c|c|c|c|c|c|c|c|}
\hline Construct & Indicator & $\begin{array}{l}\text { Loading } \\
\text { Factor }\end{array}$ & T Statistic & $\begin{array}{l}\text { Composite } \\
\text { Reliability }\end{array}$ & AVE & $\begin{array}{l}\text { The square } \\
\text { roots of AVE }\end{array}$ & $\begin{array}{l}\text { Correlation } \\
\text { between Construct }\end{array}$ \\
\hline \multirow{3}{*}{$\begin{array}{l}\text { Products of Green } \\
\text { Kampung }\end{array}$} & PGK 1 & 0.787 & 7.48 & \multirow{3}{*}{0.878} & \multirow{3}{*}{0.706} & \multirow{3}{*}{0.840} & \multirow{6}{*}{0.727} \\
\hline & PGK 2 & 0.884 & 24.29 & & & & \\
\hline & PGK 3 & 0.847 & 15.92 & & & & \\
\hline \multirow{3}{*}{$\begin{array}{l}\text { Outcomes of Green } \\
\text { Kampung }\end{array}$} & OGK 2 & 0.856 & 21.55 & \multirow{3}{*}{0.859} & \multirow{3}{*}{0.671} & \multirow{3}{*}{0.819} & \\
\hline & OGK 3 & 0.874 & 21.54 & & & & \\
\hline & OGK 4 & 0.719 & 7.32 & & & & \\
\hline
\end{tabular}

Table 8 shows a $65.1 \%$ (FIT) variable variance simplified by a complex model, which is seldom influenced and analyzes the $63.7 \%$ (AFIT) values of connected variables. In addition, GFI shows an adequate value of $0.978(>0.9)$ and SRMR=0.1211 (close to zero).This model is based on the goodness-fit characteristics and the overall significance on the $\mathrm{T}$ statistic at above 1.96, which fulfills the requirements, and is further considered fit.

Based on the model's structure and suitability evaluation, the conclusions below were reached:

1. H1: Hypothesis one (The created green kampung is an environmental innovation construct dimension): This had a 0.9301 path coefficient influence on the products, with a 46.04 value $(>1.96)$ at $5 \%$. Therefore, the postulation was discovered to be acceptable.

2. H2: (The green kampung formed is an environmental innovation construct dimension): This had a 0.9289 path coefficient influence on the outcomes, and was 45.76 (>1.96) at $5 \%$. Hence, the theory was proven to be suitable.

Table 6. Structural Model: Path Coefficients

\begin{tabular}{|c|c|c|c|}
\hline Path & $\begin{array}{c}\text { Estimate } \\
\text { Coefficient }\end{array}$ & Standard Error & T statistic \\
\hline EIGK $\rightarrow$ PGK & 0.9301 & 0.0202 & 46.04 \\
\hline EIGK $\rightarrow$ OGK & 0.9289 & 0.0203 & 45.76 \\
\hline
\end{tabular}

Table 7. Structural Model: Determination Coefficient $\left(\mathrm{R}^{2}\right)$

\begin{tabular}{|c|c|c|c|}
\hline Construct & R2 Value & $\begin{array}{c}\text { Goodness } \\
\text { Standard }\end{array}$ & Conclusion \\
\hline PGK & 0.8645 & $>0.67$ & Good \\
\hline OGK & 0.8631 & $>0.67$ & Good \\
\hline
\end{tabular}

Table 8. Goodness-fit Model

\begin{tabular}{|c|c|c|c|c|}
\hline Criteria & Estimate & $\begin{array}{c}\mathrm{T} \\
\text { statistic }\end{array}$ & $\begin{array}{c}\text { Fit } \\
\text { Standard }\end{array}$ & Conclusion \\
\hline FIT & 0.651 & 15.76 & $>0.5$ & Good \\
\hline $\begin{array}{c}\text { Adjusted FIT } \\
\text { (AFIT) }\end{array}$ & 0.637 & 14.86 & $>0.5$ & Good \\
\hline $\begin{array}{c}\text { GFI (Goodness } \\
\text { of Fit Index) }\end{array}$ & 0.978 & 168.55 & $>0.9$ & Very Good \\
\hline $\begin{array}{c}\text { SRMR } \\
\text { (Standardized } \\
\text { Root Mean } \\
\text { Square) }\end{array}$ & 0.1211 & 7.04 & $<0.1$ & Moderate \\
\hline
\end{tabular}

\section{Conclusions and Suggestions}

\subsection{Conclusions}

This study involved an empirical secondary evaluation on the generated model, and the results obtained are stated below:

1. All first order construct components for the green kampung product (PGK) dimension showed the PGK dimensional variability (70.62\%), with low plastic packaging indicators contributing the most.

2. Also, each first order component for the green kampung outcomes (OGK) denoted the green kampung outcomes dimensional variability (67.1\%), with the residents or community cadres' creativity and innovation indicators having the highest contribution percentage.

3. Meanwhile, the PGK dimensions in the secondary model contributes to the environmental innovation construct (EIGK) by 93.01\%, while, the OGK counterpart was $92.89 \%$. Hence, the two components were proven to be valid and measure the EIGK by $65.1 \%$. 


\subsection{Suggestion}

Based on this study, sufficient knowledge on how to manufacture green products outputs is necessary for environmental innovation to occur in kampungs as these goods indicate a sustainable community output. Also, eco-friendly materials obtained from household waste reduce plastic packaging and encourage recycling. This is a possible advancement measure in Surabaya and other rural areas.

In addition, domestic and international appreciation, creativity and a shared consideration for the environment are required for a successful innovation movement.

Therefore, measuring this achievement through product and outcome quantity and quality as well as and the outcomes in Surabaya city green kampungs helps to determine the achievable sustainability goals. Hence, further research is suggested to effectively determine a kampung's capacity to drive environmental innovation as this is the basis to measure performance in creating a sustainable green city.

\section{Acknowledgements}

The authors are grateful to the study area respondents for participating in the surveys and interviews, and to the Widya Kartika University (UWIKA) Research Institute for the assistance rendered. The authors are also thankful to the $\mathrm{R}$ and D Strengthening Directorate, Ministry of Research and Technology, Kemenristek-BRIN (National Research and Innovation Agency), for the financial support provided (083/SP2H/LT/DRPM/2020).

\section{REFERENCES}

[1] Kotaridis, Ioannis, and Maria Lazaridou. "Environmental Change Detection Study in the Wider Area of Lignite Mines." Civil Engineering and Architecture, vol. 6, no. 2, pp. 108-114, 2018. (https://doi.org/10.13189/cea.2018.060 207)

[2] Bong Ko, Seung, and Byoungho Jin. "Predictors of Purchase Intention toward Green Apparel Products: A Cross-Cultural Investigation in the USA and China.” Journal of Fashion Marketing and Management; Bradford, vol. 21, no. 1, pp. 70-87, 2017. ProQuest,(https://doi.org/10.1108/JFMM-072014-0057)

[3] Ashton, Weslynne, et al. "The Adoption of Green Business Practices among Small US Midwestern Manufacturing Enterprises.” Journal of Environmental Planning and Management, vol. 60, no. 12, pp. 2133-2149, 2017. (https://doi.org/10.1080/09640568.2017.1281107)

[4] Hamann, Ralph, et al. "Why Do SMEs Go Green? An Analysis of Wine Firms in South Africa.” Business \& Society, vol. 56, no. 1, pp. 23-56, 2017. (https://doi.org/10.1177/0007650315575106)
[5] Wibowo, Edwin Agung. "Mencapai Performa Bisnis Unggul Dengan Menerapkan Green Marketing Pada Perusahaan Di Indonesia.” OPINI, vol. 1, no. 4, 2016.

[6] Gürlek, Mert, and Muharrem Tuna. "Reinforcing Competitive Advantage through Green Organizational Culture and Green Innovation.” The Service Industries Journal, vol. 38, no. 7-8, pp. 467-491, 2018. (https://doi.org/10.1080/02642069.2017.1402889)

[7] Martinez, Fabien. “Toward Inclusive Economic, Social and Environmental Progress in Asia: An Introduction.” The Role of Corporate Sustainability in Asian Development, Springer, 2017, pp. 1-9. (https://doi.org/10.1007/978-3-31 9-45160-2_1)

[8] Rhee, Changyong. Asian Development Outlook 2012: Confronting Rising Inequality in Asia. Asian Development Bank, 2012.

[9] Hakim, Abdul. "Surabaya Raih Penghargaan 'Global Green City' PBB.” Antara News, 16 Feb. 2018, https://www.antaranews.com/berita/662428/surabaya-raihpenghargaan-global-green-city-pbb. (retrieved Date Accessed: 20/09/2020)

[10] Berty, Teddy T. S. "Wali Kota Surabaya Terima Penghargaan Lingkungan Dari PBB.” Liputan6.Com, 23 Nov. 2017,http://global.liputan6.com/read/3146856/wali-k ota-surabaya-terima-penghargaan-lingkungan-dari-pbb. (retrieved Date Accessed: 20/09/2020)

[11] Suprobo, F. Priyo, and Ririn Dina Mutfianti. Monograf: Kapasitas Dinamis Kampung Perkotaan Dalam Menuju Sustainable Green City (Studi Kasus Kota Surabaya). Media Sahabat Cendekia, 2019.

[12] Sari, Maya Mustika Kartika, et al. "Green and Clean as Issue on Women's Movement in Surabaya." 1st International Conference on Social Sciences (ICSS 2018), Atlantis Press, 2018. (https://doi.org/10.2991/icss-18.2018.47)

[13] Defourny, Jacques, and Marthe Nyssens. "Fundamentals for an International Typology of Social Enterprise Models." VOLUNTAS: International Journal of Voluntary and Nonprofit Organizations, vol. 28, no. 6, pp. 2469-2497, 2017. (https://doi.org/10.1007/s11266-017-9884-7)

[14] Eldar, Ofer. "The Role of Social Enterprise and Hybrid Organizations.” Colum. Bus. L. Rev., p. 92, 2017.

[15] Mongelli, Luca, et al. "Hybridisation of Diverging Institutional Logics through Common-Note Practices-an Analogy with Music and the Case of Social Enterprises.” Industry and Innovation, vol. 24, no. 5, pp. 492-514, 2017. (https://doi.org/10.1080/13662716.2017.1302793)

[16] Chang, Ching-Hsun, and Yu-Shan Chen. "Green Organizational Identity and Green Innovation." Management Decision, vol. 51, no. 5, pp. 1056-1070, 2013. (https://doi.org/10.1108/MD-09-2011-0314)

[17] Albort-Morant, Gema, Antonio L. Leal-Rodríguez, et al. "Absorptive Capacity and Relationship Learning Mechanisms as Complementary Drivers of Green Innovation Performance.” Journal of Knowledge Management, vol. 22, no. 2, pp. 432-452, 2018. (https://doi.org/10.1108/JKM-07-2017-0310)

[18] Albort-Morant, Gema, Antonio Leal-Millán, Gabriel 
Cepeda-Carrion, et al. "Developing Green Innovation Performance by Fostering of Organizational Knowledge and Coopetitive Relations.” Review of Managerial Science, vol. 12, no. 2, $\quad$ pp. 499517,2018.(https://doi.org/10.1007/s11846-017-0270-z)

[19] Albort-Morant, Gema, Antonio Leal-Millán, and Gabriel Cepeda-Carrión. "The Antecedents of Green Innovation Performance: A Model of Learning and Capabilities.” Journal of Business Research, vol. 69, no. 11, pp. 49124917, 2018. (https://doi.org/10.1016/j.jbusres.2016.04.052)

[20] Nanath, Krishnadas, and Radhakrishna R. Pillai. "The Influence of Green Is Practices on Competitive Advantage: Mediation Role of Green Innovation Performance." Information Systems Management, vol. 34, no. 1, pp. 3-19, 2017. (https://doi.org/10.1080/10580530.2017.1254436)

[21] Pereira, Ángeles, and Xavier Vence. "Factores Empresariales Clave Para La Eco-Innovación: Una Revisión de Estudios Empíricos Recientes a Nivel de Empresa.” Cuadernos de Gestión, vol. 12, no. 3, pp. 73-103, 2012. (https://doi.org/10.5295/cdg.110308ap)

[22] Wilts, Henning, et al. "Eco-Innovations for Waste Prevention-Best Practices, Drivers and Barriers." Science of the Total Environment, vol. 461, Elsevier, pp. 823-829, 2013. (https://doi.org/10.1016/j.scitotenv.2013.05.096)

[23] Huang, Jing-wen, and Yong-hui Li. "Green Innovation and Performance: The View of Organizational Capability and Social Reciprocity." Journal of Business Ethics: JBE; Dordrecht, vol. 145, no. 2, Oct., pp. 309-24, 2017. ProQuest, (http://dx.doi.org/10.1007/s10551-015-2903-y).

[24] Mioara, Borza, and Talmaciu Mihai. "Incidence of Green Business on Developing the Entrepreneurial Environment from Metropolitan Area of Iaşi." Procedia Economics and Finance, vol. 15, pp. 1201-1208, 2014. (https://doi.org/10.1016/S2212-5671(14)00579-6)

[25] Wong, Ken Kwong-Kay. "Partial Least Squares Structural
Equation Modeling (PLS-SEM) Techniques Using SmartPLS.” Marketing Bulletin, vol. 24, no. 1, pp. 1-32, 2013.

[26] Wold, H. O. "Partial Least Squares.” Kotz S, Johnson N L. Encyclopedia of Statistical Sciences. New York: Wiley, pp. 581-591, 1985.

[27] Aprilia, Karlina, and Imam Ghozali. Generalized Structured Component Analysis (GeSCA), Model Persamaan Struktural Berbasis Komponen. Penerbit Universitas Diponegoro., 2013.

[28] Chin, Wynne W. Commentary: Issues and Opinion on Structural Equation Modeling. JSTOR, 1998.

[29] Fornell, Claes, and David F. Larcker. "Evaluating Structural Equation Models with Unobservable Variables and Measurement Error.” Journal of Marketing Research, vol. 18, no. 1, Sage Publications Sage CA: Los Angeles, CA, pp. 39-50, 1981. (https://doi.org/10.1177/0022243781018001 04)

[30] Hair Jr, Joe F., et al. "Partial Least Squares Structural Equation Modeling (PLS-SEM).” European Business Review, Emerald Group Publishing Limited, 2014.

[31] Henseler, Jörg. "Partial Least Squares Path Modeling." Advanced Methods for Modeling Markets, Springer, pp. 361-381,2017.(https://doi.org/10.1007/978-3-319-53469-5 -12)

[32] Hwang, Heungsun, and Yoshio Takane. Generalized Structured Component Analysis: A Component-Based Approach to Structural Equation Modeling. CRC Press, 2014. (https://doi.org/10.1201/b17872)

[33] Hu, L., and P. M. Bentler. "Structural Equation Modeling: Cutoff Criteria for Fit Indexes in Covariance Structure Analysis: Conventional Criteria versus New Alternatives.” Structural Equation Modeling: A Multidisciplinary Journal, vol. 6, no. 1, pp. 1-55, 1999. (https://doi.org/10.1080/1070 5519909540118) 